\title{
Asupan energi, zat gizi makro, dan zat gizi mikro pada pasien hemodialisis di RSUD Panembahan Senopati Bantul
}

\author{
Ari Tri Astutia, , Septriana ${ }^{\text {a }}$ \\ aS1 Ilmu Gizi, Fakultas Ilmu Kesehatan, Universitas Respati Yogyakarta Jalan Raya Tajem km 1,5 Sleman, \\ Indonesia \\ ${ }^{1}$ triastuti.ari@gmail.com *
}

*korespondensi penulis

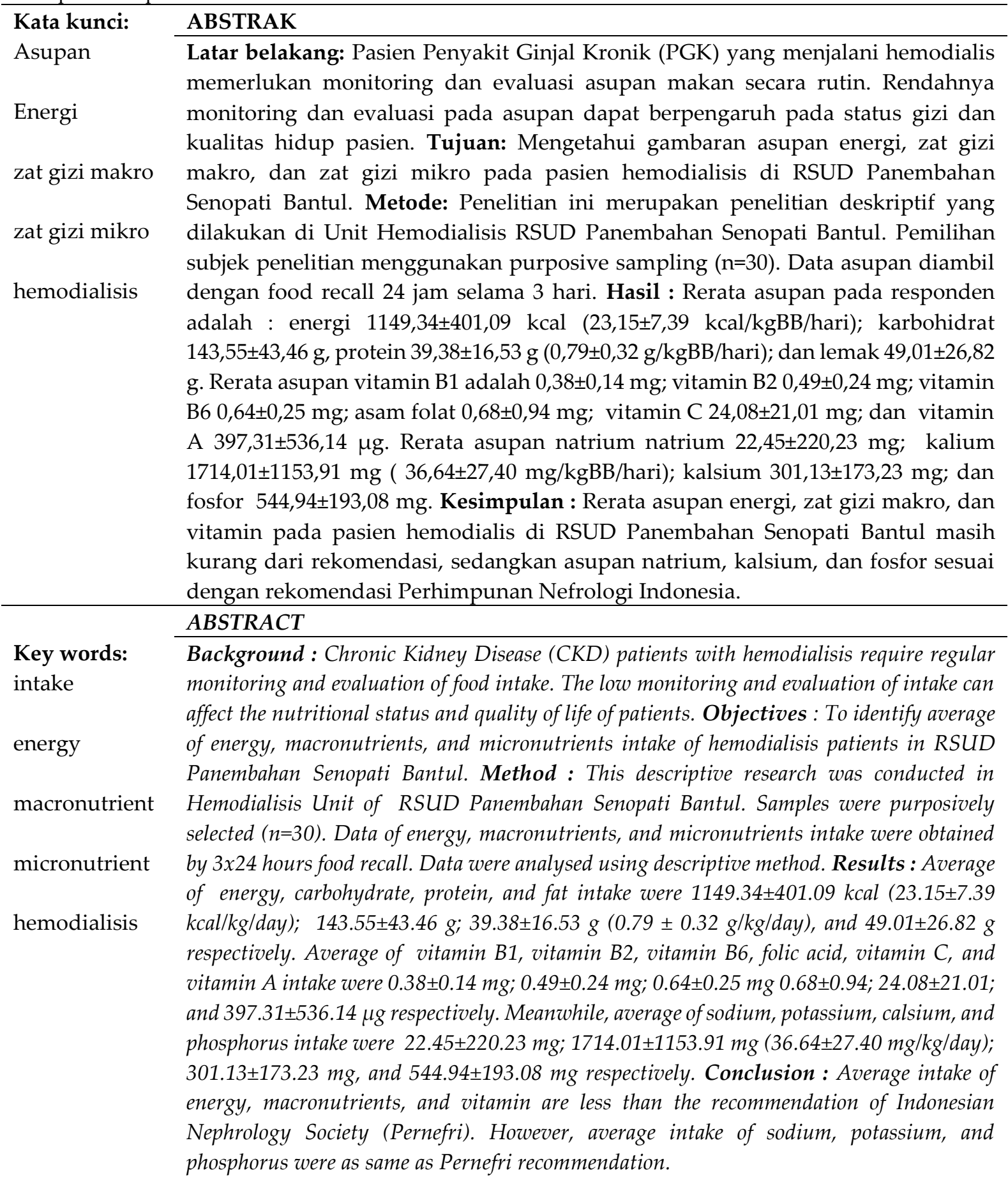

This is an open access article under the CC-BY-SAlicense. 


\section{Pendahuluan}

Asupan makan yang adekuat pada pasien hemodialisis merupakan pilar yang penting dalam menunjang status gizi dan kualitas hidup pasien Penyakit Ginjal Kronik (PGK) dalam menjalani hemodialisis. Pemberian energi yang adekuat sangat penting untuk membuat keseimbangan nitrogen menjadi positif. Selain itu, asupan zat gizi makro serta mikro yang adekuat serta sesuai anjuran juga dapat meningkatkan kualitas hidup pasien hemodialisis ${ }^{1}$.

Risiko malnutrisi juga dapat terjadi pada pasien hemodialisis karena pola makan yang tidak baik termasuk dengan adanya gangguan gastrointestinal seperti anoreksia, mual, hemodialisis yang tidak adekuat, serta hilangnya zat makanan ke dalam cairan dialisat. Gizi kurang yang terjadi pada pasien hemodialisis seharusnya dapat diperbaiki dengan memenuhi kebutuhan gizinya ${ }^{2}$.

Hemodialis akan menyebabkan peningkatan katabolisme protein karena sebesar 4-9 gram asam amino akan terbuang dalam satu sesi hemodialis. Hal inilah yang dapat meningkatkan tingginya kejadian malnutrisi energi protein pada pasien PGK yang menjalani hemodialis ${ }^{1}$. Asupan protein yang tidak adekuat berhubungan dengan rendahnya kualitas hidup pada pasien hemodialis. Rendahnya level (kadar) albumin dalam serum juga berhubungan dengan penurunan fungsi fisik, sosial, dan morbidity pasien hemodialis ${ }^{3}$. Menurut Pernefri masih banyak pasien yang mempunyai asupan pr otein di bawah anjuran yaitu 1-1,2 g/kgBB/hari ${ }^{1}$. Rerata asupan protein pasien hemodialisis masih kurang dari $1 \mathrm{~g} /$ $\mathrm{kgBB} /$ hari. Jumlah pasien PGK hemodialis yang mengalami protein defisit sebesar $18-75 \% 4$. Asupan protein pada pasien PGK yang menjalani hemodialisis lebih tinggi dibandingkan dengan pasien PGK predialisis.

Selain asupan energi dan zat gizi makro (terutama protein) yang harus diperhatikan pada pasien PGK, asupan zat gizi mikro juga harus diperhatikan. Pasien PGK berisiko mengalami defisiensi atau kelebihan satu atau lebih mikronutrien karena asupan yang tidak adekuat, gangguan absorbsi mikronutrient, gangguan metabolisme, atau akibat kehilangan atau penambahan yang didapat selama dialisis ${ }^{1}$.

Defisiensi vitamin B6 terutama dalam perannya dalam utilisasi asam amino dan metabolism lemak mempunyai peran utama sebagai coenzyme. Selain itu asam folat, vitamin B6 dan atau vitamin B12 dapat mempengaruhi fungsi normal tubuh ${ }^{5}$ Pada pasien hemodialisis terdapat risiko kehilangan vitamin B1 (thiamin), terutama apabila disertai dengan asupan protein dan kalium yang rendah. Asupan protein yang rendah juga dapat meningkatkan risiko defisiensi vitamin B2 (riboflavin), padahal terdapat peningkatan kebutuhan riboflavin selama dialisis ${ }^{1}$. Selain itu kadang suplementasi vitamin larut air juga dianjurkan karena adanya risiko kehilangan dalam cairan dialisat.

Asupan mineral mikro seperti zat besi, kalium, dan natrium juga merupakan hal yang perlu diperhatikan pada pasien hemodialisis. Kasus anemia juga sering ditemui pada pasien dialisis. Hal ini karena jumlah zat besi yang diserap di usus halus berkurang serta berkurangnya pembentukan erythropoietin karena supresi sumsum tulang belakang oleh urea. Pembatasan kalium dan sodium juga diperlukan pada pasien dialisis, terutama yang mengalami anuria ${ }^{4}$.

Asupan zat-zat gizi mikro tersebut kadang kurang diperhatikan, oleh karena itu diperlukan evaluasi lebih lanjut agar tidak berlebihan ataupun kekurangan karena dapat mempengaruhi kualitas hidup pasien PGK yang menjalani proses hemodialis. Oleh karena 
itu penelitian ini bertujuan untuk mengetahui gambaran asupan energi, zat gizi makro, dan zat gizi mikro pada pasien hemodialisis di RSUD Panembahan Senopati Bantul.

\section{Metode}

Jenis penelitian ini adalah penelitian deskriptif dan dilaksanakan di Unit Hemodialisis RSUD Panembahan Senopati Bantul dari September- Oktober 2017. Populasi penelitian ini adalah pasien yang menjalani hemodialisis rutin di RSUD Panembahan Senopati Bantul. Sampel (subjek) penelitian ini adalah pasien yang menjalani hemodialisis rutin di RSUD Panembahan Senopati Bantul yang mempunyai kriteria inklusi : 1) Pasien menjalani hemodialisis rutin 2 kali seminggu; 2) Berusia >18 tahun; dan 3) Bersedia menjadi subjek penelitian dan mengikuti prosedur penelitian. Besar sampel minimal dalam penelitian ini adalah 30 orang.

Variabel penelitian ini adalah asupan energi, asupan zat gizi makro, dan asupan zat gizi mikro. Metode pengambilan data asupan menggunakan food recall 24 jam sebanyak 3 kali tanpa berurutan. Asupan energi pasien hemodialisis dinyatakan dalam kilokalori (kcal) kemudian dibandingkan dengan kebutuhan pasien PGK hemodialis yaitu antara 30-35 $\mathrm{kcal} / \mathrm{kgBBideal}_{\text {hari }}{ }^{1}$. Asupan karbohidrat, protein, dan lemak pasien hemodialisis dinyatakan dalam gram dan dibandingkan dengan kebutuhan pasien PGK hemodialysis menurut Pernefri.1 Rekomendasi kebutuhan protein pada pasien hemodialis sebesar 1,2 g/kgBBideal/hari, lemak 25-30\% dari total kalori dan karbohidrat sisa dari kalori perhitungan untuk protein dan lemak ${ }^{1}$. Hasil asupan mineral, vitamin larut air, dan vitamin larut lemak pasien juga dibandingkan dengan kebutuhan pasien PGK hemodialis berdasarkan Pernefri ${ }^{1}$. Setelah masing-masing asupan dihitung menggunakan software Nutrisurvey, selanjutnya data dianalisis secara univariat untuk melihat distribusi frekuensi dari setiap variabel.

Pengambilan data dibantu oleh 2 orang enumerator dengan kualifikasi pendidikan terakhir S1 Ilmu Gizi. Instrumen penelitian ini menggunakan formulir food recall 24 jam, kuesioner karakteristik responden, buku foto makanan, microtoice, dan timbangan berat badan digital yang telah dikalibrasi di UPT Metrologi Legal Kota Yogyakarta dengan nomor 1511/MET/TE-369/VII/2017. Penelitian telah mendapatkan surat keterangan kelaikan etik (ethical clrearence) nomor 711.4/FIKES/PL/VIII/2017 dari Komisi Etik Penelitian Kesehatan Fakultas Ilmu Kesehatan Universitas Respati Yogyakarta.

\section{Hasil dan Pembahasan}

Responden penelitian ini adalah pasien yang menjalani hemodialis rutin di Unit Hemodialisis RSUD Penembahan Senopati Bantul. Jumlah responden penelitian adalah 30 orang. Berikut merupakan karakteristik responden penelitian yang tersaji di Tabel 1 .

Berdasarkan Tabel 1 dapat dilihat bahwa rerata usia responden adalah $(47,07 \pm 11,5$ tahun $)$ dengan usia paling muda 27 tahun dan usia paling tua adalah 70 tahun. Sebagian besar responden berjenis kelamin perempuan, tidak bekerja, tamat SMA/SMK/Sederajat/Diploma/Sarjana, mempunyai IMT normal, serta mempunyai pendapatan di bawah UMK Kabupaten Bantul.

IMT sebagian besar responden dalam kategori normal. Hal ini sesuai dengan anjuran Pernefri yang menyebutkan bahwa target penatalaksaan nutrisi pada PGK dengan hemodialisis adalah menjaga agar IMT pada kisaran $20-25 \mathrm{~kg} / \mathrm{m}^{2} .{ }^{1}$ Data IMT pada responden juga menunjukkan bahwa hampir $36 \%$ responden mempunyai berat badan lebih, bahkan ada

Ari Tri Astuti et.al (Asupan energi, zat gizi makro, dan zat gizi mikro pada pasien hemodialisis di RSUD Panembahan Senopati Bantul) 
yang obesitas. Selama menjalani hemodialiasis, komposisi massa otot, massa lemak, dan distribusi lemak mengalami peningkatan. ${ }^{6}$

Keadaan berat badan kurang juga sebaiknya dihindari pada pasien yang menjalani hemodialisis. Pada etnis Afrika-Caribia yang menjalani hemodialisis, ditemukan bahwa pasien yang mempunyai IMT $\leq 23 \mathrm{~kg} / \mathrm{m}^{2}$ mempunyai risiko kematian 2 kali lebih tinggi daripada yang lain. Hal ini mengindikasikan bahwa anjuran menjaga IMT tetap normal pada pasien yang menjalani hemodialisis merupakan hal yang dianjurkan ${ }^{7}$.

Tabel 1. Karakteristik Responden Penelitian $(n=30)$

\begin{tabular}{|c|c|c|}
\hline Karakteristik & $\mathbf{n}$ & $\%$ \\
\hline \multicolumn{3}{|l|}{ Usia $(47,07 \pm 11,5$ tahun $)$} \\
\hline \multicolumn{3}{|l|}{ Jenis kelamin } \\
\hline Laki-laki & 14 & 46,7 \\
\hline Perempuan & 16 & 53,3 \\
\hline \multicolumn{3}{|l|}{ Pekerjaan } \\
\hline Tidak bekerja/IRT & 16 & 53,3 \\
\hline Buruh tani/buruh bangunan & 8 & 26,7 \\
\hline PNS/TNI/Polri/Karyawan Swasta & 6 & 20,0 \\
\hline \multicolumn{3}{|l|}{ Pendidikan } \\
\hline Tidak sekolah/tamat SD/SMP/sederajat & 13 & 43,3 \\
\hline Tamat SMA/SMK/Sederajat/Diploma/Sarjana & 17 & 56,7 \\
\hline \multicolumn{3}{|l|}{ Pendapatan keluarga $(895.000 \pm 533.748,94$ rupiah $)$} \\
\hline$<\mathrm{UMK}^{*}$ & 26 & 86,7 \\
\hline$\geq \mathrm{UMK}$ & 4 & 13,3 \\
\hline \multicolumn{3}{|l|}{ Indeks Massa Tubuh (IMT) } \\
\hline Berat Badan kurang (underweight) & 5 & 16,7 \\
\hline Normal & 14 & 46,7 \\
\hline BB lebih (overweight) & 8 & 26,6 \\
\hline Kegemukan (obese) & 3 & 10,0 \\
\hline
\end{tabular}

Gambaran rerata asupan energi dan zat gizi makro responden diperoleh dengan survey konsumsi makanan 24 hours food recall sebanyak 3 kali (tidak berurutan). Gambaran rerata asupan tersebut kemudian dibandingkan dengan rerata kebutuhan responden yang telah dihitung berdasarkan pedoman Pernefri. ${ }^{1}$ Informasi tersebut terdapat dalam Tabel 2.

Tabel 2. Asupan dan Kebutuhan Harian Energi dan Zat Gizi Makro (n=30)

\begin{tabular}{lcc}
\hline Variabel & Asupan $($ Mean \pm SD) & Kebutuhan $($ Mean \pm SD) \\
\hline Energi (kcal) & $1149,34 \pm 401,09$ & $1638,02 \pm 284,54$ \\
Energi (kcal/kgBB/hari) & $23,15 \pm 7,39$ & \\
Karbohidrat (g) & $143,55 \pm 43,46$ & $236,42 \pm 41,07$ \\
Protein (g) & $39,38 \pm 16,53$ & $60,48 \pm 10,51$ \\
Protein (g/kgBB/hari) & $0,79 \pm 0,32$ & \\
Lemak (g) & $49,01 \pm 26,82$ & $50,05 \pm 8,69$ \\
\hline
\end{tabular}

Rerata asupan baik energi maupun zat gizi makro (karbohidrat, protein, dan lemak) sebagian besar masih kurang dari rekomendasi kebutuhan Pernefri (2011). Pada penelitian ini ditemukan bahwa rerata asupan energi pasien adalah 23,15 $\pm 7,39 \mathrm{kcal} / \mathrm{kgBB} / \mathrm{hari}$ $(1149,34 \pm 401,09 \mathrm{kcal})$. Hal ini jauh lebih rendah dari rekomendasi Pernefri yang 
menganjurkan asupan energi pada pasien ginjal kronik yang menjalani hemodialisis adalah berkisar 30-35 kcal/kgBB/hari. ${ }^{1}$ Rerata asupan protein juga kurang dari anjuran Pernefri yaitu $1,2 / \mathrm{kgBB} /$ hari. $^{1}$ Rerata asupan protein harian responden hanya mencapai $0,79 \pm 0,32$ $\mathrm{g} / \mathrm{kgBB} /$ hari $(39,38 \pm 16,53$ gram). Rendahnya asupan energi dan protein menyebabkan secara keseluruhan asupan menjadi rendah, sehingga asupan karbohidrat dan lemak juga menjadi rendah. Asupan lemak paling mendekati dari rekomendasi yang dianjurnya, walaupun belum mencapai range yang diharapkan.

Hasil ini sesuai dengan penelitian pada pasien hemodialisis di Malaysia yang menyebutkan bahwa asupan energi dan protein pada pasien hemodialisis kurang dari anjuran yang direkomendasikan. Rerata asupan energi dan protein pada penelitian sebelumnya sebesar $26,8 \pm 7,0 \mathrm{kcal} / \mathrm{kgBB} /$ hari ( $80 \%$ inadequate energy intake) dan $1,1 \pm 0,4$ $\mathrm{g} / \mathrm{kgBB} /$ hari $(75.6 \%$ inadequate protein intake) secara berurutan. Sebagian besar responden gagal untuk mencapai rekomendasi asupan, terutama energi dan protein ${ }^{6}$.

Rendahnya asupan protein juga berhubungan dengan rendahnya kualitas hidup, fungsi mental, dan fisik pada pasien hemodialisis ${ }^{3,6}$. Pasien hemodialisis yang mempunyai asupan makan yang kurang, terutama asupan energi dan protein secara konsisten berhubungan dengan risiko penurunan kesehatan serta terjadinya kematian pada berbagai macam populasi yang berbeda ${ }^{7}$.

Rendahnya asupan responden kemungkinan berhubungan dengan adanya gangguan gastrointestinal pada beberapa responden. Sebanyak 20 orang responden $(66,7 \%)$ menyatakan bahwa mereka mengalami berbagai macam gangguan gastrointestinal seperti penurunan nafsu makan, mual, muntah, sariawan, susah buang air besar, gastritis, dan kesulitan menelan karena batuk. Rendahnya asupan energi dapat disebabkan oleh penurunan nafsu makan serta penambahan usia7. Sebagian besar responden juga mempunyai pendapatan keluarga di bawah UMK Kabupaten Bantul sehingga kemungkinan daya beli responden terhadap makanan juga terbatas. Terbatasnya daya beli membuat akses terhadap berbagai macam makanan juga berkurang sehingga asupan juga cenderung berkurang.

Target penatalaksanaan nutrisi berdasarkan Pernefri adalah asupan makan pada Pasien Ginjal Kronik (PGK) yang menjalani HD dianjurkan $>80$ \% dari rekomendasi kebutuhan ${ }^{1}$. Persentase asupan energi dan zat gizi makro pada responden disajikan pada Tabel 3.

Tabel 3. Perbandingan Persentase Asupan terhadap

Kebutuhan Harian Energi dan Zat Gizi Makro (n=30)

\begin{tabular}{lcc}
\hline \multicolumn{1}{c}{ Variabel } & $\mathbf{n}$ & $\mathbf{\%}$ \\
\hline Energi & & \\
$\leq 80 \%$ & 21 & 70,0 \\
$>80 \%$ & 9 & 30,0 \\
Karbohidrat & & \\
$\leq 80 \%$ & 25 & 83,3 \\
$>80 \%$ & 5 & 16,7 \\
Protein & & \\
$\leq 80 \%$ & 23 & 76,7 \\
$>80 \%$ & 7 & 23,3 \\
Lemak & & \\
$\leq 80 \%$ & 11 & 36,7 \\
$>80 \%$ & 19 & 63,3 \\
\hline
\end{tabular}

Ari Tri Astuti et.al (Asupan energi, zat gizi makro, dan zat gizi mikro pada pasien hemodialisis di RSUD Panembahan Senopati Bantul) 
Berdasarkan Tabel 3 dapat dilihat bahwa persentase asupan sebagian besar (energi, karbohidrat, protein) masih $<80 \%$ dari rekomendasi kebutuhan yang dianjurkan Pernefri. Persentase asupan yang lebih baik terdapat pada lemak. Hal ini menunjukkan bahwa perlunya monitoring dan evaluasi lebih lanjut berkaitan dengan asupan energi dan zat gizi makto yang belum memenuhi target penatalaksanaan dari Pernefri.

Selain asupan energi dan zat gizi makro yang perlu dimonitor, asupan zat gizi mikro juga perlu dimonitor. Gambaran asupan zat gizi mikro yang meliputi vitamin dan mineral dapat dilihat pada Tabel 4.

Tabel 4. Asupan dan Kebutuhan Harian Zat Gizi Mikro Responden ( $\mathrm{n}=30$ )

\begin{tabular}{lcc}
\hline \multicolumn{1}{c}{ Zat Gizi Mikro } & Asupan (Mean \pm SD) & Rekomendasi* $^{*}$ \\
\hline Vitamin Larut Air & & \\
Vitamin B1/ thiamin (mg) & $0,38 \pm 0,14$ & $1-1-1,2$ \\
Vitamin B2/ riboflavin (mg) & $0,49 \pm 0,24$ & $1,1-1,3$ \\
Vitamin B6/ Piridoksin (mg) & $0,64 \pm 0,25$ & 10 \\
Asam folat/B9 (mg) & $0,68 \pm 0,94$ & 1 \\
Vitamin C (mg) & $24,08 \pm 21,01$ & $75-90$ \\
Vitamin Larut Lemak & & \\
Vitamin A ( $\mu$ g) & $397,31 \pm 536,14$ & $700-900$ \\
Mineral dan trace element & & \\
Na (mg) & $322,45 \pm 220,23$ & $5000-6000$ \\
Kalium (mg) & $1714,01 \pm 1153,91$ & $630,00 \pm 109,44$ \\
Kalium (mg/kgBB/hari) & $36,64 \pm 27,40$ & $8-17$ \\
Kalsium (mg) & $301,13 \pm 173,23$ & $\leq 2000$ \\
Fosfor & $544,94 \pm 193,08$ & $800-1000$ \\
\hline
\end{tabular}

*Rekomendasi Pernefri, 2011

Rerata asupan vitamin memang masih kurang dari rekomendasi (Tabel 4). Asupan zat gizi mikro seperti natrium, kalsium, vitamin A, dan B2 berhubungan dengan malnutrisi dan inflamasi pada pasien peritoneal dialysis ${ }^{8}$. Selain itu pada sebuah studi juga tidak ditemukan perbedaan yang signifikan pada keaneragaman vitamin yang dikonsumsi pada pasien hemodialisis baik yang malnutrisi maupun tidak ${ }^{8}$. Hal ini karena memang karakteristik pasien peritoneal dialisis dan hemodialisis memang berbeda.

Defisiensi asam folat dan B12 sering ditemukan pada pasien Penyakit Ginjal Kronik. Defisiensi tersebut dapat memicu hyperhomocysteinemia yang diduga merupakan faktor penyebab banyak penyakit jantung dan pembuluh darah. Terapi dialisis dapat mengurangi kadar vitamin larut air (termasuk asam folat dan vitamin B12) pada pasien, oleh karena itu dianjurkan untuk dilakukan suplementasi pada pasien hemodialisis dan peritoneal dialisis ${ }^{9}$. Konsumsi asam folat sebanyak $10 \mathrm{mg}$ yang diberikan 3 kali setiap minggu setelah hemodialisis selama 6 bulan dapat menormalkan kadar homocystein pada sebagain besar pasien9. Vitamin B12 sebagian besar terikat protein sehingga kehilangan saat dialisis lebih sedikit dibandingkan dengan vitamin larut air lainnya, oleh karena itu untuk suplementasi vitamin B12 belum dianjurkan ${ }^{1}$.

Suplementasi juga diperlukan karena dapat menstimulasi sistem imun disfungsi saraf autonomic pada pasien hemodialisis ${ }^{10}$. Vitamin B6 merupakan salah satu faktor yang berhubungan dengan inflamasi pada Pasien Ginjal Kronik dan hemodialisis. Defisiensi vitamin B6 dapat terjadi pada pasien dialisis yang mendapat terapi erythropoietin stimulating 
agent (ESA) ${ }^{11}$. Vitamin B6 ini dipakai untuk sintesis hemoglobin, sehingga ESA dapat menyebabkan penurunan kadar eritrosit yang mengandung vitamin B61.

Kehilangan vitamin C (asam askorbat) saat dialisis rutin bisa mencapai 33\%-40\%. Selain itu vitamin $C$ (ascorbic acid) mudah mengalami oksidasi menjadi dehydro-ascorbic acid selama hemodialisis sehingga kadarnya berkurang. Oleh karena itu, kadang suplementasi vitamin C ini juga dibutuhkan pada pasien hemodialisis, apabila dari makanan tidak mencukupi ${ }^{12}$. Namun, menurut Pernefri, sampai saat ini belum ada bukti yang mendukung bahwa suplementasi vitamin $\mathrm{C}$ akan mengurangi stres oksidatif dan risiko penyakit kardiovaskuler pada pasien penyakit ginjal tahap akhir ${ }^{1}$. Kebanyakan yang kadang perlu dianjurkan suplementasi memang cenderung pada vitamin larut air, namun untuk vitamin larut lemak seperti vitamin A, B12, dan vitamin E, vitamin K perlu dipikirkan lebih lanjut ${ }^{12}$.

Rerata asupan mineral natrium dan kalsium (Tabel 4) sudah sesuai anjuran Pernefri ${ }^{1}$. Asupan mineral fosfor cenderung masih kurang dari rekomendasi, namun masih dalam batas aman untuk mencegah hiperpospatemia. Hal yang perlu diperhatikan adalah tingginya asupan kalium pada responden yang lebih dari rekomendasi perlu dijadikan catatan bagi tenaga medis. Risiko hiperkalemia dapat terjadi pada keadaan tersebut. Tingginya prevalensi defisiensi trace element (mineral mikro) pada pasien hemodialis dalam studi sebelumnya mengindikasikan bahwa kadang suplementasi zat gizi mikro mungkin diperlukan. Untuk menghindari suplementasi yang berlebihan, dokter, perawat serta ahli gizi memang benarbenar harus menanyakan kepada pasien tentang konsumsi suplemen, terutama zat gizi mikro, terutama memeperingatkan untuk menghindari dosis tinggi vitamin A, kalium, dan tembaga ${ }^{12}$.

Penelitian ini terbatas pada gambaran asupan saja sehingga memang tidak bisa menilai indikator biokimia. Asupan yang rendah terutama zat gizi mikro (vitamin dan mineral) belum menggambarkan tingkat kandungan zat gizi mikro tersebut di dalam darah, sehingga diperlukan penelitian lebih lanjut.

\section{Kesimpulan dan Saran}

Rerata asupan energi, zat gizi makro, dan vitamin masih kurang dari rekomendasi tata laksana gizi Perhimpunan Nefrologi Infonesia. Rerata asupan mineral natrium, kalsium, dan fosfor sudah sesuai dengan rekomendasi tata laksana Perhimpunan Nefrologi Indonesia. Perlu dijadwalkan anamnesis asupan secara rutin oleh instalasi gizi minimal 3 bulan sekali (sesuai anjuran Pernefri) pada pasien hemodialisis untuk menghindari rendahnya asupan secara terus-menerus.

\section{Reference}

1. Pernefri. Konsensus Nutrisi pada Pasien Gagal Ginjal Kronik. Jakarta: Perhimpunan Nefrologi Indonesia; 2011

2. Zuyana L, Andriani M. Perbedaan Asupan Makan dan Status Gizi antara Pasien Hemodialisis Adekuat dan Inadekuat Penyakit Ginjal Kronik. Jurnal Ilmiah Media Gizi Indonesia. 2013; 9(1):13-19.

3. Ohri-Vachaspati P, Sehgal AR. Quality of life implications of inadequate protein nutrition among hemodialysis patients. Journal of Renal Nutrition.1999;9(1):9-13

4. Gunes FE. Medical Nutrition Therapy for Hemodialysis Patients. InTech; 2013 
5. Wierzbicki AS. Homocysteine and cardiovascular disease: a review of the evidence. Diab Vasc Dis Res.2007;4:143-50.

6. Yusop NB, Mun CY, Shariff ZM, Huat CB. Factors Associated with Quality of Life among Hemodialysis Patients in Malaysia. PLoS ONE.2013;8(12)

7. Foucan L, Merault H, Velayoudom-Cephise FL, Larifla L, Alecu C, Ducros J. Impact of protein energy wasting status on survival among Afro-Caribbean hemodialysis patients: a 3-year prospective study. Springer Plus.2013; 4:452

8. Chen J, Zhang K, Xiao L, Yuan Z, Chen J, Wang Z, et al. The Insufficiency Intake of Dietary Micronutrients Associated with Malnutrition-Inflammation Score in Hemodialysis Population. PLoS ONE.2013; 8(6)

9. Delfino VAD, de Andrade Vianna AC, Mocelin AJ, Barbosa DS, Mise RA, Matsuo T. Folic acid therapy reduces plasma homocysteine levels and improves plasma antioxidant capacity in hemodialysis patients. Nutrition.2007;23 : 242-247

10. Fukuda S, Koyama H, Kondo K, Fujii H, Hirayama Y, Tabata T, Okamura M, Yamakawa T,Okada S, Hirata S, Kiyama H, Kajimoto O, Watanabe Y, Inaba M, Nishizawa Y. Effects of Nutritional Supplementation on Fatigue, and Autonomic and Immune Dysfunction in Patients with End-Stage Renal Disease: a randomized, Double-Blind, Placebo-Controlled, Multicenter Trial. PloS ONE.2015;10(3)

11. Chen CH, Yeh EL, Chen CC, Huang SC, Huang YC. Vitamin B-6, Independent of Homocysteine, Is a Significant Factor in Relation to Inflammatory Responses for Chronic Kidney Disease and Hemodialysis Patients.BioMed Research International.2017(9)

12. Jankowska M, Rutkowski B, Debska-Slizien A. Vitamins and Microelement Bioavailability in Different Stages of Chronic Kidney Disease. Nutrient.2017; 9(3):282 